\title{
The Terms of Trade of Food Producers as a Mechanism of Rural Differentiation
}

\section{Charles Gore}

Discussion of the agricultural terms of trade usually focuses on year-to-year trends to see whether there has been an increase or decrease in the general level of producer prices (or the prices of particular agricultural commodities) relative to the prices of the goods and services which farmers purchase. Analyses within poor countries have been directed towards determining whether there has been a transfer of resources from rural areas to towns (Young 1971; Maimbo and Fry, 1971; Fry 1975; and Lipton 1977), from agricultural to non-agricultural sectors (Mellor 1973), or from poor rural producers to rich urban consumers (Elliott 1975). This paper examines how the terms of trade of food producers can act as a mechanism perpetuating and intensifying economic inequality both within and between rural communities.

A process of rural differentiation can occur because of the commodity structure, the seasonal structure and the spatial structure of the barter terms of trade. The first of these factors has been identified in trend analyses of the terms of trade which disaggregate producer prices by commodity, and I do not wish to dwell on it here. Clearly, if different agricultural commodities exhibit different price trends and if farmers specialise in particular crops or livestock, those farmers producing the commodities whose prices rise fastest (or fall slowest) are better off than those specialising in other commodities. This can act as an important mechanism generating regional income inequalities because of ecological limits to production (see, for example, Leff 1972), and if there are economic and social constraints preventing farmers from switching amongst commodities, differences in price trends between commodities can widen economic disparities between individuals as well as between areas.

The focus of the present paper is the seasonal and spatial structure of the terms of trade. Seasonal and spatial variations in producer prices and the rural cost of living have been obscured in trend analyses of average national prices. The omission of these dimensions is perhaps not surprising as they compound problems of data collection which are already severe. But the inability to conduct statistical analyses to specify the precise nature of a relationship should not prevent the identification of that relationship. The purpose of the present paper is to direct attention to variations in the seasonal and spatial structure of the terms of trade which are creating systematic economic disparities within the rural sector, and which recur in many poor countries. While no attempt is made to conduct a price index analysis disaggregated by season and location, the argument is based on field research in southern Ghana, and some evidence of the scale of seasonal and spatial price differences in that country is presented.

\section{Seasonal structure}

Seasonal variations in the terms of trade of food producers arise because of seasonality in both producer prices and the rural cost of living. Seasonal movements in producer prices are inevitable for all commodities which have an annual rhythm of harvesting but they are particularly strong in economies where storage facilities are rudimentary and losses consequently high; where farmers are poor and so do not have the cash reserves necessary to delay marketing after harvest; where interest rates are high and so rich merchants prefer to use capital providing loans rather than storing commodities; where high transport costs, a lack of transport facilities (especially lorries) and imperfect market information leave farming localities poorly integrated into the regional and national market; and where processing industries, which may preserve perishable commodities, are undeveloped. Seasonal fluctuations tend to be most severe in those regions where ecological constraints narrow the range of production possibilities and limit the timing of harvests to a few months each year.

Taking Ghana as an example, what is the magnitude of seasonality in producer prices? Somewhat perversely, we must start the discussion at the urban end of the market chain and then work back, for it is only in the large towns that there are reasonably reliable price data over a long period of time. Rourke (1971) 
has computed seasonal indices ${ }^{1}$ of wholesale prices for eight staple foodstuffs (the most important locally-consumed crops in the agricultural economy) in three major urban markets using time series which mainly extend from 1957 to 1970 . He finds that local rice. cocoyam and garri exhibit the least seasonality. with monthly indices between $90(89$ for cocoyam and local rice) and 110 ; millet and guinea corn show more marked seasonality. with indices fluctuating between 80 ( 79 for millet) and 120: whilst plantain. yams and maize show the most marked seasonality. with indices fluctuating from 70 to 146 . from 79 to 130 . and from 77 to 136 respectively. One may expect seasonal fluctuations in producer prices to be at least as large as these. and probably larger. As Jones (1968) has observed on Nigeria. there are two logical reasons for this: firstly. some traders store produce: secondly. and. perhaps more significantly. as the majority of traders do not undertake seasonal arbitrage. urban centres receive supplies from several areas with different harvesting dates and so the impact of local gluts and shortages is muted.

Fragments of evidence on producer prices suggest marked seasonality. From my own field observations in the Forest Belt of southeastern Ghana in 1974 and 1975. maize prices increased by between two and three times from the months in which the major harvest was reaped to the pre-harvest months. Cassava and cocoyam. both harvested throughout the year, increased by between 50 per cent and 100 per cent: and plantain. also harvested throughout the year but with marked seasonality in the marketed surplus. increased by 400 per cent. The scale of these movements is particularly significant as the Forest Belt is the most benign ecological region for farming in the country, with two rainy seasons and the production of a range of substitutable staples with varied harvesting dates. and so seasonal movements may be expected to be more dramatic in other parts of the country. Further north, in the Middle Belt of the country. Nyanteng and Van Apeldoorn (1971) observe that in the late 1960s maximum yam and maize prices in each crop year were between two and four times greater than minimum prices, though with limited data they can discern no pronounced seasonal pattern for shelled groundnuts, konkonte and local rice. In the far northeast of the country. Bauer

1 The index for each month is an average of the ratio of prices for that month to the appropriate 12 -month moving average.
(1954) shows that prices ${ }^{2}$ of late millet, guinea corn and groundnuts just befort harvest were between two and eight times as great as levels ruling immediately after. though his evidence dates from the 1940s and the pattern may have improved.

These data are admittedly mere fragments in a complicated patchwork. but they point towards widespread and surprisingly large seasonal price movements for many crops. including some major cash-earners. Let us examine their distributional implications. assuming for the moment that seasonality in the rural cost of living neither counteracts nor reinforces the resultant swings in the terms of trade.

The distributional impact of fluctuations in producer prices depends on the magnitude of seasonal movements. on the commodity structure of individual producers marketed surplus. and most critically. on differences in the ability of producers to sell when prices are high. For commodities whose supply cannot be controlled. all farmers are equally affected by price fluctuations. But for commodities which are harvested seasonally and can be stored. producers without cash reserves invariably sell at the time of year when prices are lowest (and terms of trade least favourable) whilst those with cash reserves invariably wait for a good price. Generally, two types of producer have cash reserves: large-scale producers. and those with a steady off-farm income (for exainple. from trading). Storage costs may reduce the real value of the seasonal price increase but in Ghana. at least, traditional methods of storage often result in negligible losses over the short period from harvest time to two or three months after. by which time prices are significantly higher. ${ }^{3}$ The economic consequence of the seasonal movement in producer prices is that rich producers. who can aftord to defer salt. your after your receive more for their output than others, thus intensifying existing disparities within rural communities.

Trend analyses of the magnitude of seasonal price movements can reveal a further important pattern which may be illustrated by maize prices in southeastern Ghana in the first half of the 1970s. During that period there was rapid

\footnotetext{
2 The units of sale suggest that his data apply to retail prices hut, as argued above, producer price fluctuations may be expected to be at least as large.

3 I make this assertion on the basis of my own field observa tions, though the scanty published evidence on the subject is contradictory-see Nyanteng (1972).
} 
inflation of producer prices for maize but at the sane time there was an increase in seasonal fluctuations as prices at the time of the major harvest were increasing much more slowly than prices in the pre-harvest months. For example, in Asestwa, the major rural assembly market for maize in southeastern Ghana, the lowest price for a bag of maize during the 1970-71 crop year ((July-Junc) was about $\mathrm{N} \not 8.00$, and in the four subsequent years it was approximately $N \not 9.00$, $\mathrm{N} \varnothing 10.00, \mathrm{~N} \not 11.00$, and $\mathrm{N} \notin 12.00$. In contrast, the highest prices in the corresponding five crop years were about $\mathrm{N} \notin 18.00, \mathrm{~N} \notin 30.00, \mathrm{~N} \notin 30.00$, $N \notin 23.00$ and $N \$ 38.00$. Thus trend analyses of year-to-year changes in tcrms of trade of food productes, which reveal that they have not detcriorated. or even that they have improved, may hide the fact that they have moved against producers who sell at harvest time. Interestingly, there is the possibility of a feedback mechanisn characterised by incrcasing seasonal fluctuations if, as economic disparities increase. a larger proportion of the total marketed surplus is sold in the inmediate post-harvest months.

Seasonal fluctuations in the prices of the goods and services which producers purchase are less severe than fluctuations in producer prices. The seasonal tluctuations in Ghana are not sufficient to counteract producer price fluctuations, and sometimes they reinforce them. For cxample, in the cocoa-grciwing belt, prices of such commcdities as sandals, buckets, pans, toys, children's dresses, khaki cloth, and singlets increase slightly during the main cocoa harvest, from September to December, when there is an injection of cash into the economy, but this is precisely the time when prices of food staples are low. Seasonal movements of some commodities are prohibited as the government fixes control prices, but during periodic shortages black market prices prevail. The impact of these price increascs on the farmer is ncgligible as long as he can defer consumption.

The most significant distributional impact of seasonal movements in purchased goods and services arises when producers have to buy locallyproduced lood. Most producers aim to satisfy the majority of their food consumption requirements themselves, but in northern Ghana some small-scale producers do not harvest enough to tide them over the lean season and they find themselves in the individious position of buying locdstult's at the time of year when prices are highest, having sonctimcs (owing to pressing casit needs) sold the same commodities at the time of year when prices were lowest (see Songsore
1975). The seasonal structure of the terms of trade can thus impose a double penalty on poor producers, and if rich producers within the community are acting as part-time traders buying up farm produce when it is cheap and selling later when it is dear, there is a magnified redistributive effect within rural communities. Polly Hill (1972) has described this situation precisely in northern Nigeria.

\section{Spatial structure}

Just as the seasonal structure of the terms of trade imposes a double penalty on some poor producers, their spatial structure imposes a double penalty on all rural communities remote from the urban centres which are the source of village imports and the destination of food exports Spatial variations in the terms of trade are particularly marked in economies where the marketing system is technically inefficient and pricing uncompetitive; where the urban population, and thus food demand, is concentrated in a few large cities; where a large proportion of the goods pur chased by farmers is imported through the national ports; and where local manufacturing industries, government services, and wholesaling activities are concentrated in a lew urban centres. When a single primate city acts as both the major source of village imports and destination for food exports, there is likely to be a perfect correlation between the ternis of trade and distance from that centre (Kelley 1976). The further a producer lives from that centre, the less he gets for the farm produce he sells and the more he pays for the goods and services he buys.

What is the scale of spatial variations in the terms of trade? Spatial variation in rural prices is an even more neglected topic than seasonal fluctuations and I shall only present some indirect evidenci from Ghana, relating mainly to producer prices.

Onc may presume that producer prices are deternincd by the demand and supply situation in each locality but the upper limit to the price is set by the cost of transport to the urban centres where the produce is consumed, and the lower limit is ste by the cost of production. Theoretically, when marketing channels are competitive, producer prices will be less than wholesale prices in the urban centres by an amount equivalent to the transport costs to those centres, and when marketing channels are monopolistic, prices will be below this level but above a hypothetical breakeven point at which prices are so low that 
the farmer feels that it is not worthwhile to produce for the market beyond his essential cash needs. My indirect evidence will thus consist of data on the comparative disadvantage of different farming lccalities in terms of transport costs to urbain markets and the competitiveness of ruraluro:tn nlarketing links.

Contrary to expectations, rural-urban transport costs are not very significant in generating differences in producer prices between communities. Transport costs from village markets to urban centres rarely absorb more than 10 per cent of the final retail price. even for low value, bulky goods and for long distance hauls, and so the cost disadvantige of conmunities near to and far from the urban centres are not very different. For example, in February 1975, the cost of conveying a bag of maize to Koforidua in south. eastern Ghana (when the prevailing wholesale price was approximately $N \notin 24.00)$ was $N \not 0.60$ from Okrakwadjo (12 miles from town): $N \not 1.00$ from Asesewa (30 miles away); $N \notin 1.60$ from Ahamahamasu (46 miles); $\mathrm{N} \varnothing 2.50$ from Ejura (184 miles); and $N \notin 3.00$ from Alebubu (222 miles).

Local transport rates within rural areas are much higher than rural-urban rates and so the small difference in distance between a producer living in a village market centre and another living in a village five miles into the bush can create a surprisingly large cost disadvantage. This is particularly true if farmers have to headload produce to the initial point of sale. I recorded the following rates for headloading a bag of maize to Obuoho (a village market centre near Koforidua) in 1974-75: $1 \frac{1}{4}$ miles-N $(0.60 ; 2$ miles -N $£ 1.50 ; 4$ miles-N£2.40. Furthermore, in addition to these financial costs, there are the opportunity costs of the farmers' selling time. an extremely complex variable to measure but one which is very important to the producer.

Differences in the competitiveness of rural-urban marketing channels tend to reinforce the transport cost disadvantage of remote communities. In Ghana, most of the major consumption centres are in the Forest Belt or along the coast and the main buyers in many Savannah localities are longdistance wholesalers. Entry into this activity is constrained by large capital and skill requirements and so long distance trading channels tend to be more monopolistic than locial channels. Communities within the Savannah which are locally remote (off the main motorable roads) are at a particular disadvantage, as visiting buyers tend to concentrate on more accessible localities until supplies are exhausted. In the Forest Belt in areas close to the major consumption centres, producers in locally remote communities (more than four miles from a village narket centre) nuay similarly face an uncompetitive selling situation as most local traders preter to buy in village markets with direct commercial lorry connections with the urban centres. But whereas the buyers in this type of locality are a few out of many local traders, buyers in locally remote localities in the Savannah are a few out of a small number of long distance traders.

This is necessarily a brief. and somewhat oversimplified, sketch. but what I am suggesting is that those localities with the greatest transport cost disadvantage are likely to be the same as those with the greatest trading margin disadvantage, and that, if village comnunities are arranged along a continuum according to the level of producer prices. at one extreme one will find villages in remote localities within remote districts whilst at the other extreme will be villages in accessible localities within accessible districts. My own field research suggests that in the first type of locality producers sometines receive less than 40 per cent of the urban retail price whilst in the last type they nay receive more than 70 per cent.

Turning to spatial variations in the prices of gocds and services which producers purchase, we enter a terra incognita. In Ghand, the government control prices ensure that there are only small regional differences in some commodities some of the time but, as stated earlier, black market pricing prevails periodically. I do not wish to speculate on the size of price differentials between rural comnunities but merely to re-emphasize that spatial variations in the rural cost of living compound the locational disadvantages of remote rural communities. Communities which receive less for their farm produce are likely to pay more for the goods and services which they purchase.

The distributional consequences of the spatial structure of the terms of trade are felt between farming localities. Whether the terms of trade are moving in favour or against producers in general, some cononunities are persistently worse off than others and the systematic bias against particular communities arises through their location. This factor is generating "spatial disparities" within the rural sector just as the seasonal structure of the terms of trade is generating social disparities between individuals within a community.

However. the social and spatial dimensions are interdependent. The power of seasonal price 
fluctuations as a mechanism of economic differentiation depends on the importance of commodities with marked seasonality in the farmers' marketed surplus. Inaccessibility to urban centres constrains the range of commodities that can be profitably sold, and if the commodities which are unprofitable in remote localities are also those with least seasonality, the distributional impact of the seasonal structure of the terms of trade will be most strongly felt within remote villages.

Furthermore, assuning that there are no seasonal fluctuations in trading margins and transport costs, the relative disadvantage of remoteness will be much greater for poor farmers than for rich farmers. We may illustrate this point with a hypothetical (though, in Ghanaian terms, not totally unrealistic) example. Let us take two farming localities in which producers sell maize destined for consumption in the only urban centre in the country. The price they receive is equivalent to the urban wholesale price minus transport costs to each locality. Suppose it costs NC1.00 to ship one bag of maize to the urban centre from one locality; N\&6.00 from the other. The urban wholesale price per bag is $\mathrm{N} \not 12.00$ at harvest time and $N \notin 36.00$ in the month before harvest. A small-scale producer selling at harvest time thus receives $N \notin 11.00$ per bag in the accessible locality but only $N \notin 6.00$ in the inaccessible one; a large-scale producer storing and selling just before harvest time receives $N \notin 35.00$ per bag in the accessible locality and $N \notin 30.00$ per bag in the inaccessible one. Thus whereas the poor farmer in the remote locality gets approximately 55 per cent of the price received by the poor farmer in the accessible locality, the rich farmer in the remote locality gets approximately 86 per cent of his rich counterpart.

\section{Conclusion}

This paper has been concerned to show how two hidden dimensions of the barter terms of trade, their seasonal and spatial structure, can act as mechanisms of economic differentiation within the rural sector. The analysis is partial, as variations in the real income of producers depend on variations in output as well as on the barter terms of trade, and so such factors as access to land, tenure arrangements, loan restrictions, and access to technical innovations which can increase productivity are the fundamental determinants of rural inequality. However, variations in the barter terms of trade complement these production-side factors, because the real prices which the farmers receive determine both the amount of capital available for productive investment and the incentive for increasing or decreasing production.
In poor countries in which there are significant seasonal fluctuations and spatial variations in prices, the terms of trade of food producers are an important link in the complex of causes perpetuating and intensifying rural inequality.

\section{References}

Bauer, P. T., 1954, West African Trade, Cambridge University Press, Cambridge

Elliott, C., 1975, Patterns of Poverty in the Third World, Praeger, New York

Fry, J., 1975, 'Rural-urban terms of trade, 196073: A note', African Social Research, 19

Hill, P., 1972, Rural Hausa: A Village and a Setting, Cambridge University Press, Cambridge

Jones, W. O., 1968, 'The structure of staple food marketing in Nigeria as revealed by price analysis', Food Research Institute Studies, 8

Kelley, K. B., 1976, 'Dendritic central place systems and the regional organisation of Navajo trading posts' in C. A. Smith (ed), Regional Analysis, Volume I, Economic Systems, Academic Press, New York

Leff, N. H., 1972, 'Economic development and regional inequality: origins of the Brazilian case', Quarterly Journal of Economics, 86

Lipton, M., 1977, Why Poor People Stay Poor, Maurice Temple Smith, London

Maimbo, F. J. M. and J. Fry, 1971, 'An investigation into the change in the terms of trade between the rural and urban sector of Zambia', African Social Research, 12

Melior, J. W., 1973, Accelerated growth in agricultural production and intersectoral transfer of resources,' Economic Development and Cultural Change, 22

Nyanteng, V. K., 1972, 'The storage of foodstuffs in Ghana,' Technical Publication Series, No. 18, Institute of Statistical, Social and Economic Research, University of Ghana, Legon

Nyanteng, V. K. and G. J. van Apeldoorn, 1971, 'The Farmer and the Marketing of Foodstulfs', Technical Publication Series, No. 19, Institute of Statistical, Social and Economic Research, University of Ghana, Legon

Rourke, B. E., 1971, Wholesale prices of starchy foods in the major urban centres in Ghana, The Economic Bulletin of Ghana, 1:2

Songsore, J., 1975, Wa Town as a Growth Centre 1897-1973, unpublished $\mathrm{PhD}$ thesis, University of Ghana, Legon

Young, C. E., 1971, 'Rural-urban terms of trade,' African Social Research, 12 